\title{
Photosensitisation combined with ozone gas delays the postharvest ripening of stored tomato
}

\section{Sayali More and T.V. Ramana Rao*}

P.G. Department of Biosciences,

Sardar Patel University,

Vallabh Vidyanagar-388 120, Gujarat, India

Email: sayali.more0588@gmail.com

Email: tadapanenirao@yahoo.com

*Corresponding author

\begin{abstract}
Tomato faces pathogen attack which is a major cause of postharvest losses. The present study is carried out to minimise its postharvest losses and to extend its shelf life by physical elicitors such as photosensitisation, ozone and UV-C. The quality of the fruit was evaluated by the quantitative analysis of physico-chemical, biochemical and enzymatic assay at a regular interval of $5 \mathrm{~d}$ during storage. The results showed significantly higher levels of total phenols, ascorbic acid, carotene, lycopene and the antioxidant activity throughout their storage as compared to control. The fruits of T5 group (photosensitisation and ozone gas treatment) remained marketable up to $40 \mathrm{~d}$, while the non-treated fruits were acceptable up to $22 \mathrm{~d}$. The nutritional quality of stored tomato was also found better in treated fruit than control. These results suggest that the photosensitisation and ozone is found effective in the postharvest extension of tomato and maintaining their nutritional quality.
\end{abstract}

Keywords: ozone gas; photosensitisation; shelf life; tomato; UV-C irradiation.

Reference to this paper should be made as follows: More, S. and Rao, T.V.R. (2020) 'Photosensitisation combined with ozone gas delays the postharvest ripening of stored tomato', Int. J. Postharvest Technology and Innovation, Vol. 7, No. 1, pp.42-55.

Biographical notes: Sayali More is a doctoral research student of Biosciences Department of Sardar Patel University, Gujarat state, India. Her research is mainly focused on the optimisation and evaluation of safe post-harvest technologies for improvement of shelf-life and quality maintenance of some short-lived tropical fruits. She presented her work at various national and international conferences.

T.V. Ramana Rao is a Professor of Botany in the Biosciences Department of Sardar Patel University, Gujarat. India. His major areas of research interest are postharvest physiology of fresh and minimally processed fruits and vegetables with major emphasis on the improvement of health promoting properties and shelf life extension. He has published several research articles in refereed national and international journals. He is a recipient of several awards and fellowship of national and international repute.

This paper is a revised and expanded version of a paper entitled 'Photosensitization in combination of ozone gas delays the postharvest ripening of stored tomato' presented at Posters session of CSIR-IICT Platinum Jubilee International Conference on 'Biotechnological Research and Innovation for Sustainable Development', CSIR IICT, Hyderabad, 22-25 November 2018. 


\section{Introduction}

Tomato (Solanum lycopersicum) belongs to the family Solanaceae is the most important commercial crop in the world and also it is a climacteric fruit which is prone to several postharvest diseases due to pathogens (Kimura and Sinha, 2008). India stands second to China in the production of tomato with $11 \%$ of global production. As per horticulture statistics at a glance 2018, India produces 19,759 thousand MT of tomatoes in which Madhya Pradesh and Andhra Pradesh are the leading states for producing tomatoes and $12.44 \%$ of total production of tomatoes get rotten. Tomatoes are not only the source of variety of nutrients but are also having health promoting antioxidants like lycopene and carotenoid (Arab and Steck, 2000). Aidoo et al. (2014) attributed the economic loss of tomato cultivation to the post-harvest losses. These losses are due to the diseases and short storage life has become global concern since it causes massive loss of horticultural yield; approximately $25 \%$ of fruits are spoiled due to postharvest diseases (Ahmed et al., 2017).

Tomato is susceptible to multiple bacterial, fungal, viral and pathogens which ultimately results in postharvest losses (Martínez-Castro et al., 2018). To overcome this problem various chemicals and fungicides are being used but these chemicals are harmful for human consumption and it has overreached for research efforts using other safe eco-friendly alternatives (Tusiime, 2014).

Photosensitisation is a novel disinfection technique involving the use of photoactive component (sodium chlorophyllin) and LED lights. The exposure of fruits to LED lights triggers ample of phototoxic reactions and eventually kill the surface microorganisms (Paskeviciute and Luksiene, 2009). Another technique involves ozone as a potent disinfecting agent. As an oxidising agent in organic reaction, ozone is used in many food industries (Pandiselvam et al., 2017). Ultraviolet-C (UV-C) irradiation treatment has been successfully applied on a wide range of fresh produce including climacteric and non-climacteric fruits and the beneficial effects of UV-C hormesis include pathogen resistance, delayed chlorophyll degradation and improved nutritional content (Scott et al., 2018). Therefore, the current study has been focused on surface sterilisation by non-thermal disinfection techniques like photosensitisation, ozone treatment and UV-C irradiation.

\section{Material and methods}

Tomato fruit cv. 'Himsona' was harvested at their physiological maturity from the farm located in the vicinity of Bakrol village, Anand district of Gujarat, India. Tomatoes were transported to the research laboratory within one hour of harvesting. Fruits selected were free from any kind of visible defect and injuries.

The elicitor treatments applied on the tomato fruits are as follows:

T1 Photosensitisation alone

T2 UV-C (20 $\mathrm{min})$ alone

T3 Ozone gas (200 $\mathrm{mg} / \mathrm{h}$ for $30 \mathrm{~min})$ alone

T4 Photosensitisation and UV-C 
T5 Photosensitisation and ozone gas

T6 UV-C and ozone gas

T7 Ozone gas, UV-C and photosensitisation, C-Control (washed with water).

\subsection{Application of the treatments}

The method followed for application of this treatment was described by Luksiene and Paskeviciute (2011). Tomatoes were soaked in $1 \mathrm{mM}$ sodium chlorophyllin solution for five minutes and then air dried. The dried tomatoes were placed in treatment chamber and they were exposed to LED light at wavelength of $400 \mathrm{~nm}$ for $20 \mathrm{~min}$. After application of the tomatoes were stored in controlled atmosphere, i.e., $25^{\circ} \mathrm{C}$ and $50 \% \mathrm{RH}$.

Ozone treatment was applied on tomato fruits by keeping them in a container and covered with aluminium foil. The probe of the ozoniser (Kent ozoniner) was inserted through the aluminium foil for proper contact between ozone gas and fruit surface.

\subsection{Determination of weight loss percentage}

The electronic weighing scale (Essae DS-252) was used to weigh fresh tomatoes and during the treatment and study intervals. The weight loss during storage time was expressed in percentage using following formula given in the standard method of AOAC (1994).

$$
W(\%)=W_{i}-W_{t} / W_{i} * 100
$$

$W-P L W, W_{i}-$ Initial weight of fruit

$W_{t}-$ Weight during storage.

\subsection{Estimation of $p H$ and total soluble solids}

The digital $\mathrm{pH}$ metre (EI, 101) was used to measure $\mathrm{pH}$ and hand refractometer (Atago, Japan) was used to record the total soluble solid (TSS). The sample was prepared by crushing $1 \mathrm{~g}$ of fruit tissue with $10 \mathrm{~mL}$ of distilled water. The results were calculated using standard method given in AOAC (1994).

\subsection{Determination of total phenolic content and total antioxidant activity}

The total phenolic content in the methanolic extract of tomato ( $1 \mathrm{~g}$ of tomato tissue crushed in $10 \mathrm{~mL}$ of methanol) was estimated by Folin-Ciocalteu reagent method (McDonald et al., 2001). The total phenolic content of the extract was calculated using Gallic acid as a standard and expressed as $\mathrm{g} \mathrm{kg}^{-1}$.

DPPH (Diphenyl-2-picrylhydrazyl) free radical scavenging assay was performed for determining antioxidant activity. DPPH solution was prepared by dissolving DPPH powder $\left(0.06 \mathrm{~g} \mathrm{~L}^{-1}\right)$ in methanol and for estimation of antioxidant activity, this solution was added to supernatant which was extracted by crushing of $1 \mathrm{~g}$ of fruit tissue in $10 \mathrm{~mL}$ of methanol. The reaction mixture was made up to $3 \mathrm{~mL}$ and the absorbance of the sample was measured at wavelength of $517 \mathrm{~nm}$ after incubating samples in the dark for 30 min (Brand-Williams et al., 1995). 


\subsection{Determination of ascorbic acid}

Ascorbic acid (Vitamin C) content was estimated by the method of Kapur et al. (2012) with a slight modification. The extract prepared by crushing $1 \mathrm{~g}$ of fruit tissue in $10 \mathrm{~mL}$ of $6 \%$ of meta-phosphoric acid and $2 \mathrm{M}$ glacial acetic acid. The aliquot $(0.2 \mathrm{~mL})$ volume was up to $1 \mathrm{~mL}$ by $6 \%$ of meta-phosphoric acid and $2 \mathrm{M}$ glacial acetic acid and then mixed with $1 \mathrm{~mL}$ of $2 \%$ di-nitrophenyl hydrazine (DNPH) and $30 \mu \mathrm{L}$ of $10 \%$ thiourea and incubated at room temperature for $3 \mathrm{~h} .5 \mathrm{~mL}$ of $85 \%$ cold sulphuric acid was then added to terminate the reaction and absorbance was recorded at wavelength of $540 \mathrm{~nm}$ and expressed as $10 \mathrm{~g} \mathrm{~kg}^{-1}$.

\subsection{Determination of the lycopene and carotene pigments}

Lycopene and carotene pigments were extracted from tomato fruit tissue $(1 \mathrm{~g})$ with $10 \mathrm{~mL}$ of hexane: acetone (60:40). Absorbance was measured by using UV-VIS spectrophotometer at wavelength of 502 and $450 \mathrm{~nm}$ respectively against reagent blank and it was expressed as $\mathrm{mg} \mathrm{kg}^{-1}$ (Wang et al., 2007).

\subsection{Assay of the antioxidant enzyme}

Superoxide dismutase (SOD) was performed by observing the nitro-blue tetrazolium (NBT) reduction by the method described by Cao et al. (2007). $5 \mathrm{~g}$ of tissue was homogenised with $10 \mathrm{~mL}$ of extraction buffer $(50 \mathrm{mM}$ sodium phosphate buffer, $\mathrm{pH} 7.5$ and $1 \% \mathrm{PVP})$. The activity was assayed by making $3 \mathrm{~mL}$ of reaction mixture $(0.1 \mathrm{~mL}$ enzyme extract, $75 \mu \mathrm{M}$ of NBT, and $20 \mu \mathrm{M}$ of riboflavin, $0.1 \mathrm{mM}$ EDTA, $13 \mathrm{mM}$ methionine and $50 \mathrm{mM}$ potassium phosphate buffer, $\mathrm{pH}$ 7.8). One set of reaction mixture was exposed to $4000 \mathrm{~lx}$ light and the other set was kept in dark for $20 \mathrm{~min}$. One unit of SOD activity expressed as the amount of enzyme required to inhibit the $50 \%$ of NBT reduction at wavelength of $560 \mathrm{~nm}$ and expressed as $\mathrm{U} \mathrm{mg}^{-1}$ protein (Cao et al., 2007).

\subsection{Determination of cell wall degrading enzyme}

Extraction and assay of polygalacturonase (PG) enzyme was carried out by following the method described by Srivastava and Dwivedi, (2000). One gram of tomato tissue was homogenised with $10 \mathrm{~mL}$ of $20 \mathrm{mM}$ sodium phosphate buffer, $\mathrm{pH}$ 7.0. The extract was centrifuged at $4{ }^{\circ} \mathrm{C}$ for $30 \mathrm{~min}$. The supernatant was used as an aliquot and the reaction mixture was containing sodium acetate buffer $(200 \mathrm{mM})$, Sodium chloride $(200 \mathrm{mM})$, polygalacturonic acid (1\%). The enzyme activity was expressed as $\mathrm{U} \mathrm{mg}^{-1}$ protein.

\subsection{Estimation of protein}

Protein content was estimated by following the method described by Lowry et al. (1951) for calculating the specific activity of enzymes.

\subsection{Statistical analysis}

The data obtained from all the experiments carried out in triplicate was analysed by using SPSS software. Mean comparisons were performed using HSD of Tukey's test, Duncan 
and Dunnet tests to examine if differences between treatments and storage time were significant at $\mathrm{P}<0.05$. The overall least significance difference (LSD; $p \leq 0.05$ ) was calculated and used to determine significant differences among all the treatments and control set (Bico et al., 2009).

\section{Results and discussion}

\subsection{Changes in the weight loss percentage of tomato fruits}

Weight loss observed in control was much more apparent than in treated fruits (Figure 1). The loss of weight might be due to the transpiration and respiration processes which affected the metabolic activity in stored tomatoes (Kumar et al., 2018). Control fruits showed about $64.76 \%$ of weight loss, while fruits treated with the combination of photosensitisation and ozone (T5) showed 40.88\% weight loss till 40th d of storage. Followed by this, the tomatoes treated with photosensitisation showed $48.25 \%$ of weight loss. Reduced percentage of weight loss in tomatoes treated with ozone has also been reported by Rodoni et al (2010). The combination of photosensitisation and ozone affected the metabolic rate of stored tomatoes which resulted in the reduced loss of weight, also photosensitisation alone treatment could successfully reduce the weight loss.

Figure 1 Effect of photosensitisation, UV-C irradiation and ozone gas on physiological loss of weight (see online version for colours)

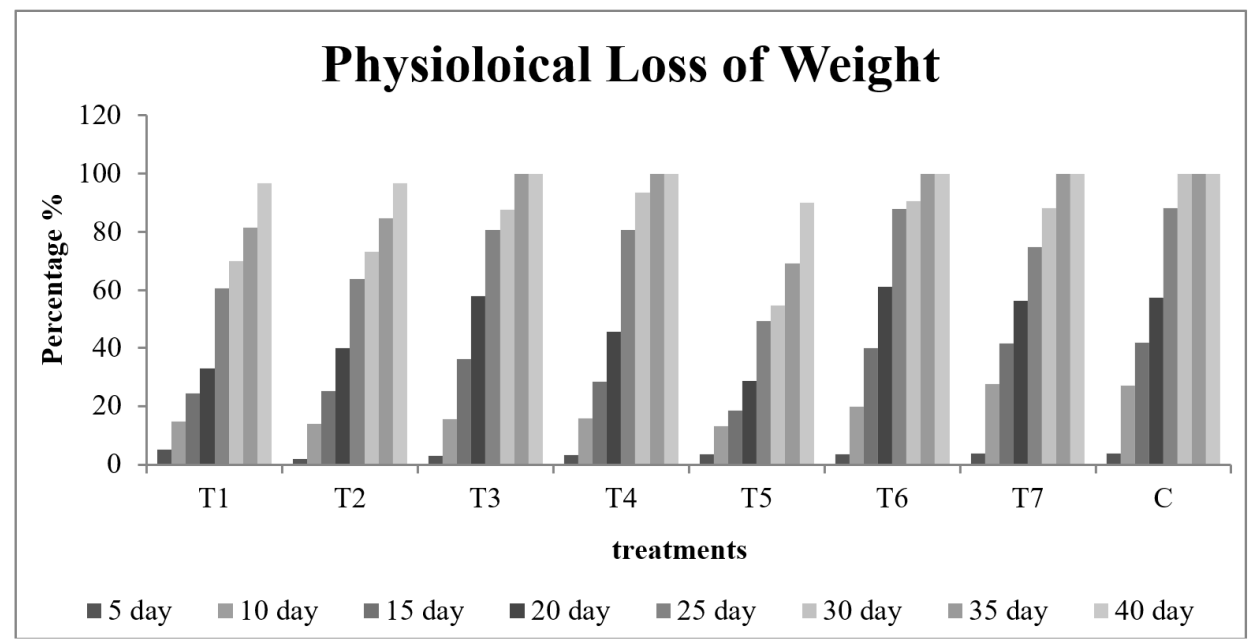

Notes: T1 - Photosensitisation alone; T2 - UV-C alone 210-280 nm; T3 - ozone gas alone $(200 \mathrm{mg} / \mathrm{h}) ; \mathrm{T} 4$ - photosensitisation and UV-C; T5 - photosensitisation and ozone gas; T6 - UV-C and ozone gas; T7 - photosensitisation + UV-C + Ozone gas and $\mathrm{C}-$ control. Different letters over the bars represents significant difference between different treatments on the same storages day at $P \leq 0.05$ according to DMRT. 
Table 1 Effect of photosensitisation, UV-C irradiation and ozone gas on $\mathrm{pH}$ and total soluble solids

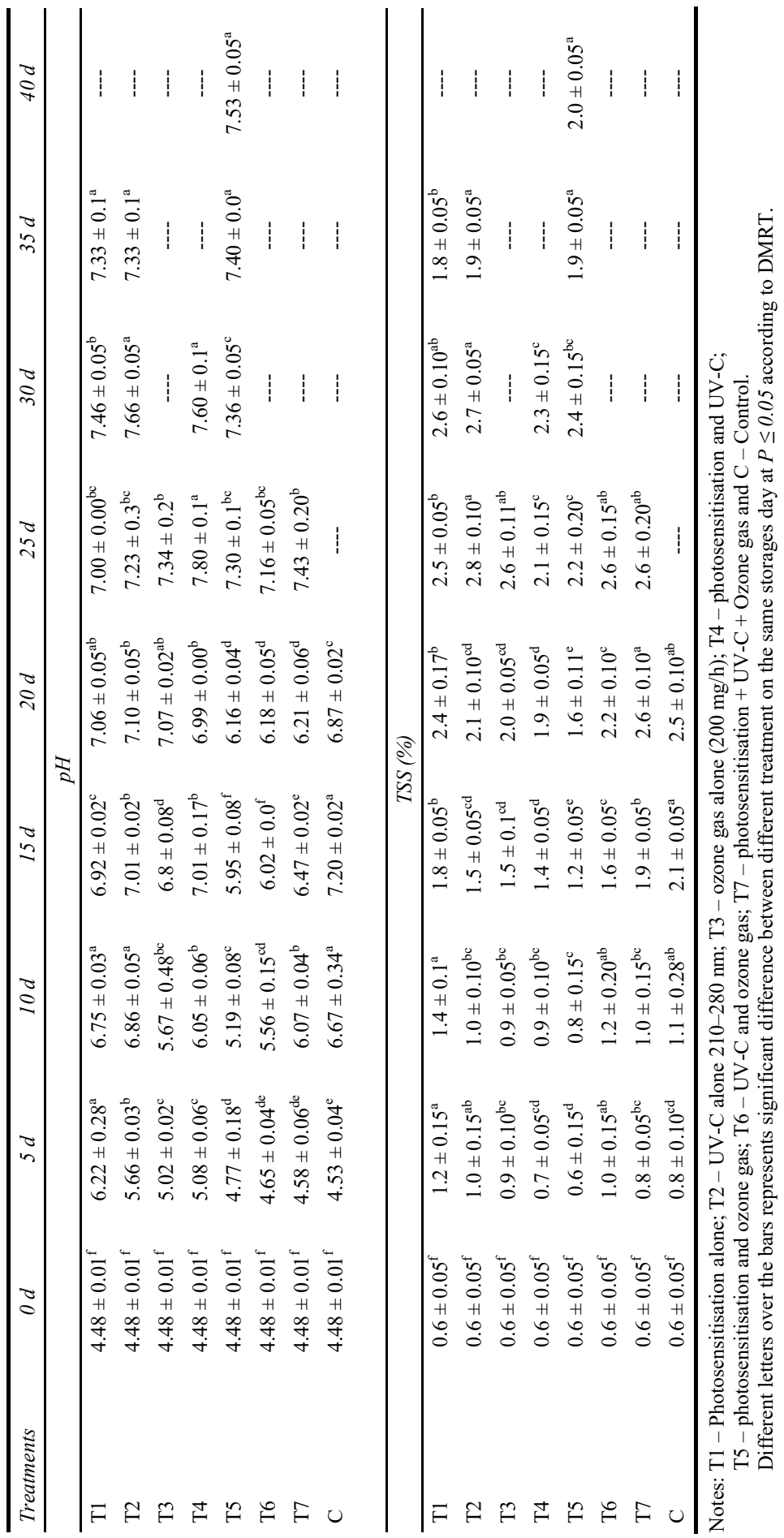


Table 2 Effect of photosensitisation, UV-C irradiation and ozone gas on total phenols and antioxidant activity of stored tomato

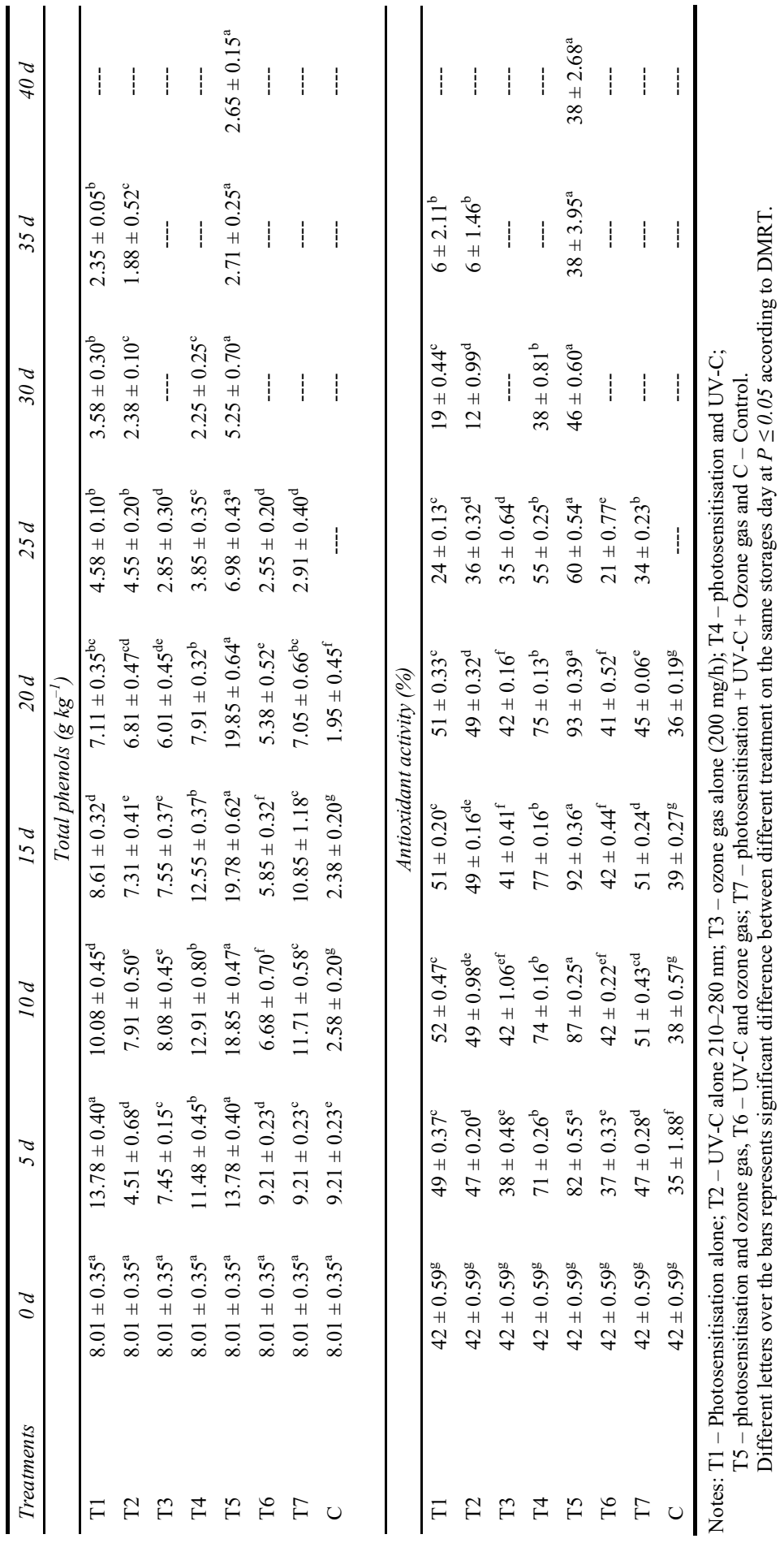




\subsection{Changes in the $\mathrm{pH}$ and TSS of tomato fruits}

In general, the $\mathrm{pH}$ and TSS of the freshly harvested tomatoes is lower due to its high organic acid contents which produced through Kreb's Cycle. As the storage time increased, the $\mathrm{pH}$ and TSS were also gradually increased. A similar increasing pattern was reported by Kumar et al. (2018). In control set, the $\mathrm{pH}$ and TSS observed on $0 \mathrm{~d}$ was 4.48 and $0.6 \%$ respectively (Table 1 ). On 20 th $\mathrm{d}$, the $\mathrm{pH}$ and TSS observed in control was 6.80 and $2.5 \%$ respectively. On other hand, tomatoes kept in T5 showed 6.12 and $1.6 \%$ respectively which was significantly lower than that of the control. T5 showed slower rate of increment in $\mathrm{pH}$ and TSS throughout the storage period; this is probably due to the combination of photosensitisation and ozone slowed down the conversion of organic acids into sugars. The similar results of slowing down of ripening of fruits were reported by Luksiene and Paskeviciute (2011) and Zambre et al. (2010).

\subsection{Changes in the total phenolic content and total antioxidant activity of tomato fruits}

The changes in total phenolic content and antioxidant activity of tomatoes are depicted in Table 2. In general, the astringency is depending upon the phenolic contents of the fruit which gives the protection to the fruit from stress produced by either pathogen or atmosphere (Tucker et al., 1993). The amount of total phenols and antioxidant activity estimated in tomatoes treated with T5 was significantly higher $(p<0.05)$ than any other treatment throughout the storage. Total phenols present in tomatoes on very first day were $8.01 \mathrm{~g} \mathrm{~kg}^{-1}$, and on 10th and 15 th $\mathrm{d}$ of storage total phenols present in tomatoes kept in T5 were $18.85 \mathrm{~g} \mathrm{~kg}^{-1}$ and $19.78 \mathrm{~g} \mathrm{~kg}^{-1}$ respectively, while in control it showed about $2.58 \mathrm{~g} \mathrm{~kg}^{-1}$ and $2.38 \mathrm{~g} \mathrm{~kg}^{-1}$ respectively and then it decreased with storage period. On other hand, a similar pattern was observed in antioxidant activity of stored tomatoes. Antioxidant activity estimated on $0 \mathrm{~d}$ was $42.6 \%$ and on 5 th $\mathrm{d}$ it reached up to $82.17 \%$ in T5, followed by $71.22 \%$ in T4 and $35.12 \%$ in control. On 20th d, the significantly higher activity was observed in T5, i.e., 93\% and lowest activity was observed in $36.80 \%$ in control. This pattern of increment of phenolic compounds and antioxidant activity in tomatoes treated with $\mathrm{T} 5$ is might be due to these physical elicitors trigger the stress response of the fruit after harvest.

\subsection{Changes in ascorbic acid content of tomato fruits}

The amount of ascorbic acid got changed in treated and control fruits during the storage (Figure 2). The ascorbic acid is used as a respiratory substrate for energy generation and hence it got decreased as fruits start to ripen after harvest (Tucker et al., 1993). Ascorbic acid content was also changed on 5 th $\mathrm{d}$ in all treated and untreated fruits than $0 \mathrm{~d}$. On 15 th $\mathrm{d}$ storage, the ascorbic acid content in the control was $0.0510 \mathrm{~g} \mathrm{~kg}^{-1}$ and in tomatoes treated with T5 had $0.0810 \mathrm{~g} \mathrm{~kg}^{-1}$ of ascorbic acid content which was significantly higher than that of the control or any other treatment. On 20th d of storage, where ascorbic acid content in all tomatoes including treated and control found to be decreased but and the tomatoes treated with T5 showed slight increment i.e. $0.0810 \mathrm{~g} \mathrm{~kg}^{-1}$. This may due to the slow ripening and controlled metabolic rate of the fruit because of the physical elicitors. 
Figure 2 Effect of photosensitisation, UV-C irradiation and ozone gas on ascorbic acid content

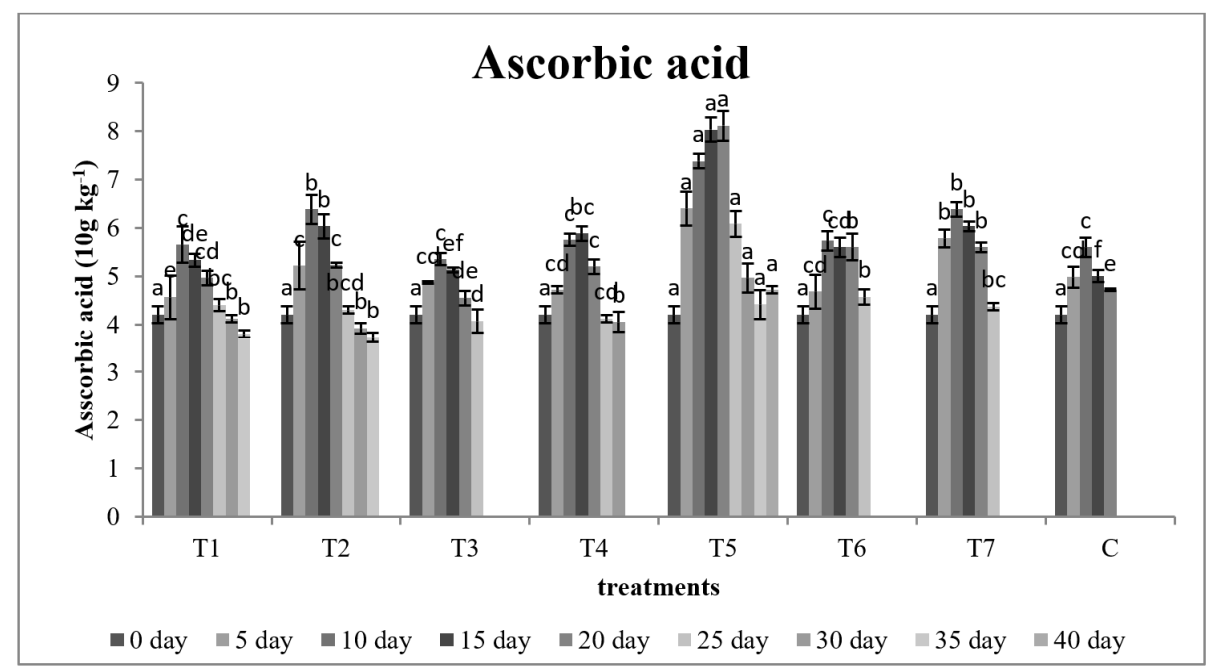

Notes: T1 - Photosensitisation alone; T2 - UV-C alone 210-280 nm; T3 - ozone gas alone $(200 \mathrm{mg} / \mathrm{h}) ; \mathrm{T} 4$ - photosensitisation and UV-C; T5 - photosensitisation and ozone gas; T6 - UV-C and ozone gas; T7 - photosensitisation + UV-C + ozone gas and $\mathrm{C}-$ control. Different letters over the bars represents significant difference between different treatments on the same storages day at $\mathrm{P} \leq 0.05$ according to DMRT.

\subsection{Changes in the lycopene and carotene content of tomato}

These are the most crucial components which take part in antioxidant activity of the fruit (Kumar et al., 2018). The colour changes from green to dark red were visible in all tomatoes during their growth and ripening (Figures 3 and 4). The chlorophyll degradation accompanying with the synthesis of colour pigments like carotene and lycopene takes place with the interference of enzyme chlorophyllase, which gives rise to the orange and red colour to the tomato from green colour (Paliyath et al., 2008). All the treated tomatoes showed slow rate of changing their colour from orange to red than that of the control. On $0 \mathrm{~d}$, the carotene and lycopene content of tomato was $1.18 \mathrm{mg} \mathrm{kg}^{-1}$ and $0.39 \mathrm{mg} \mathrm{kg}^{-1}$, respectively. On 5th $\mathrm{d}$ of storage the lycopene content in control was found highest than any other treatment, whereas on same day T5 showed significantly lower amount of lycopene content. On 20th d storage highest lycopene content, i.e., $3.54 \mathrm{mg} \mathrm{kg}-$ ${ }^{1}$ and lowest carotene content, i.e., $0.12 \mathrm{mg} \mathrm{kg}^{-1}$ was found in tomatoes kept in control set; while tomatoes kept in T5 showed $2.08 \mathrm{mg} \mathrm{kg}^{-1}$ of lycopene and $0.28 \mathrm{mg} \mathrm{kg}^{-1}$ of carotene content. At the end of storage, the lycopene and carotene content found in T5 was $4.32 \mathrm{mg} \mathrm{kg}^{-1}$ and $0.04 \mathrm{mg} \mathrm{kg}^{-1}$ respectively. These findings indicate that the treatment $\mathrm{T} 5$ could successfully slowed down the rate of conversion of carotene in to lycopene; this may due to reduced production of ethylene which directly linked to the pigment formation. The slow rate of red colour accumulation due to ozone was also noticed by Zambre et al. (2010). 
Figure 3 Effect of photosensitisation, UV-C irradiation and ozone gas on lycopene content

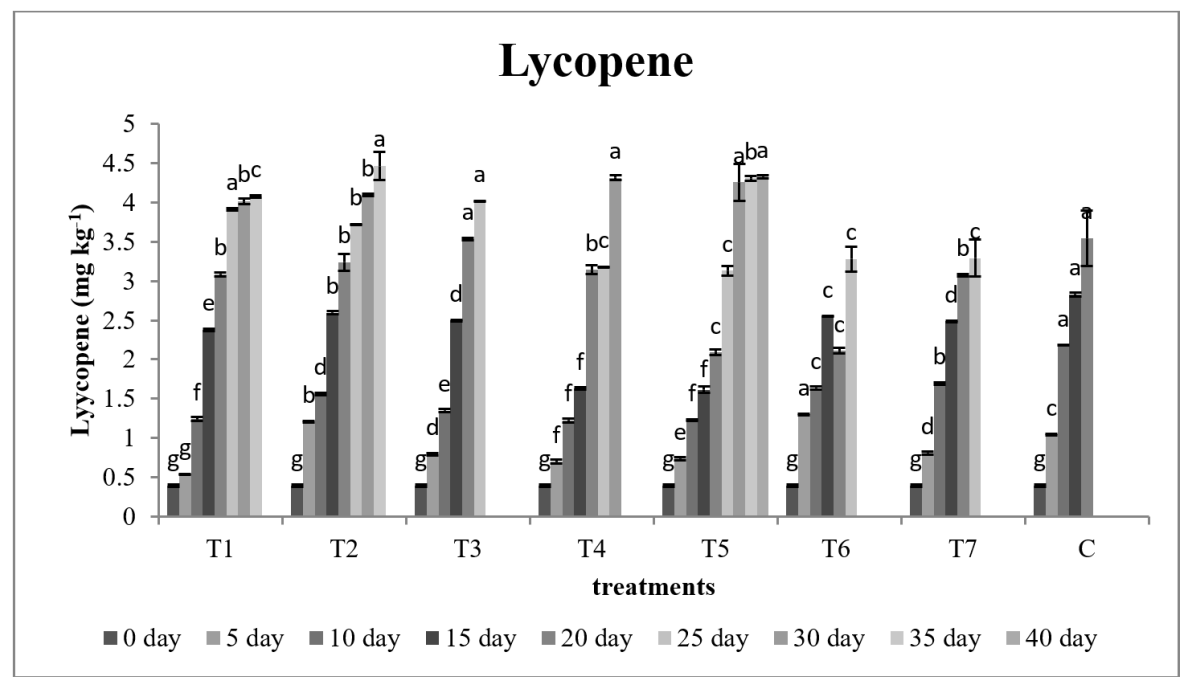

Notes: T1 - Photosensitisation alone; T2 - UV-C alone 210-280 nm; T3 - ozone gas alone $(200 \mathrm{mg} / \mathrm{h}) ; \mathrm{T} 4$ - photosensitisation and UV-C; T5 - photosensitisation and ozone gas; T6 - UV-C and ozone gas; T7 - photosensitisation + UV-C + Ozone gas and $\mathrm{C}-$ control. Different letters over the bars represents significant difference between different treatments on the same storages day at $P \leq 0.05$ according to DMRT.

Figure 4 Effect of photosensitisation, UV-C irradiation and ozone gas on carotene content

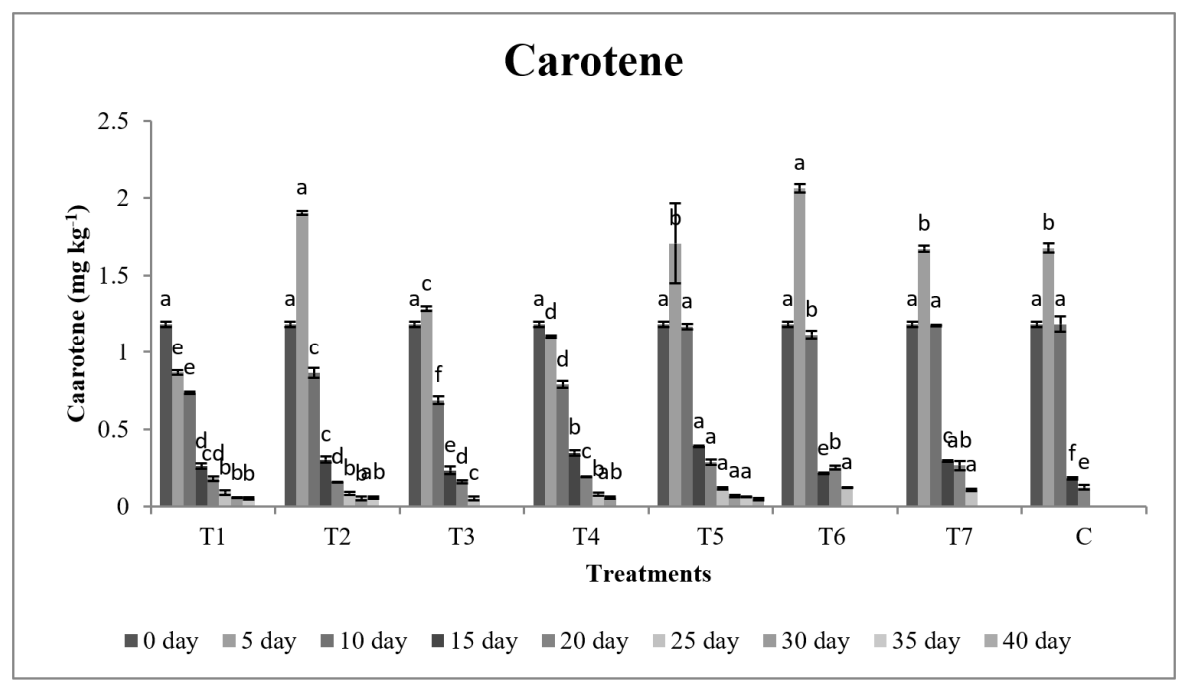

Notes: T1 - Photosensitisation alone; T2 - UV-C alone 210-280 nm; T3 - ozone gas alone $(200 \mathrm{mg} / \mathrm{h}), \mathrm{T} 4$ - photosensitisation and UV-C; T5 - photosensitisation and ozone gas; T6 - UV-C and ozone gas; T7 - photosensitisation + UV-C + Ozone gas and $\mathrm{C}-$ control. Different letters over the bars represents significant difference between different treatments on the same storages day at $P \leq 0.05$ according to DMRT. 


\subsection{Changes in the activity of antioxidant enzyme SOD of tomato}

Plant inducing stress is the most important cause for increasing reactive oxygen species which damage the protective mechanism of the fruit (Ong et al., 2014). The increase in the SOD enzyme activity could hold back the production of free radicals which eventually damage the cell (Lemoine et al., 2010). Figure 5 shows the activity of SOD during the storage period. The SOD activity found in tomatoes on $0 \mathrm{~d}$ was $5.83 \mathrm{U} \mathrm{mg}^{-1}$ protein, while on 5th d tomatoes kept untreated showed reduced SOD activity, i.e., 2.77 $\mathrm{U} \mathrm{mg}^{-1}$ protein where as $\mathrm{T} 1$ and $\mathrm{T} 5$ showed to be increased SOD activity, i.e., $8.86 \mathrm{U} \mathrm{mg}^{-1}$ protein and $9.08 \mathrm{U} \mathrm{mg}^{-1}$ protein, respectively. SOD activity of all tomatoes kept in treated as well as in control was decreased with storage time. More noteworthy results were noticed on day 10th, where control showed about $2.51 \mathrm{U} \mathrm{mg}^{-1}$ protein, the tomatoes kept in $\mathrm{T} 1$ and $\mathrm{T} 5$ showed $8.80 \mathrm{U} \mathrm{mg}^{-1}$ protein and $9.11 \mathrm{U} \mathrm{mg}^{-1}$ protein activity of SOD. It can be concluded that the T1 and T5 increased in SOD activity, which remained higher till the end of storage of the tomatoes. These results of increment of SOD activity by the physical elicitors like ozone and UV-C are in accordance with the results obtained by Gutiérrez et al. (2018).

Figure 5 Effect of photosensitisation, UV-C irradiation and ozone gas on SOD activity

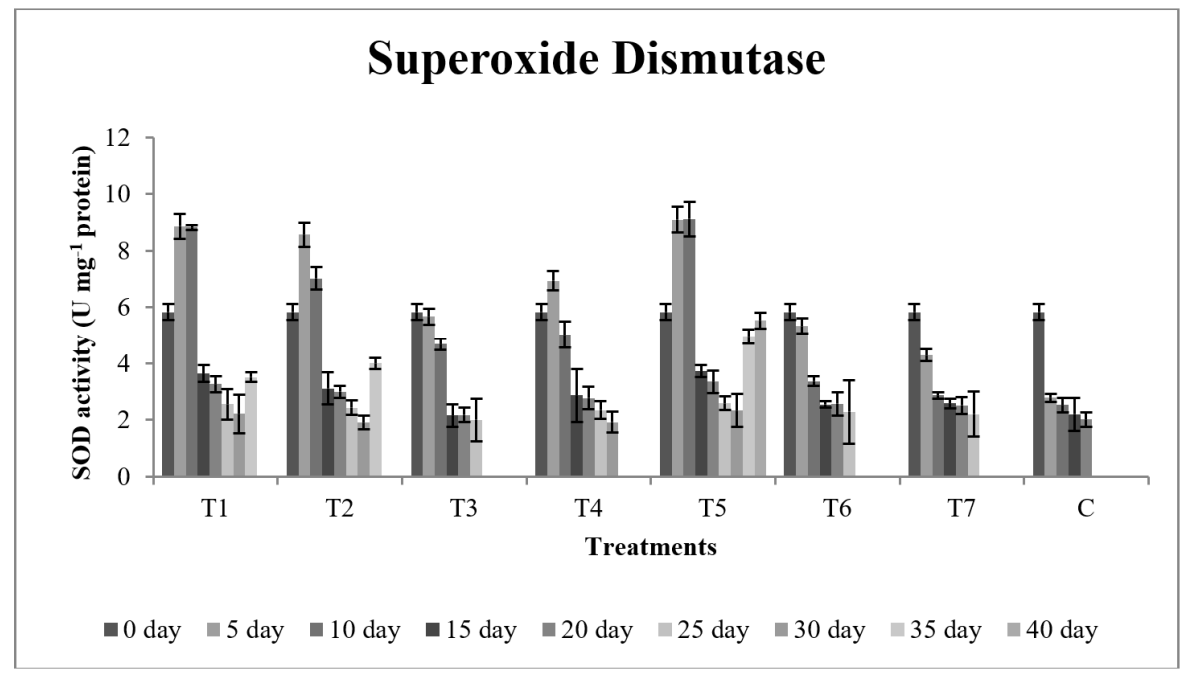

Notes: T1 - Photosensitisation alone; T2 - UV-C alone 210-280 nm; T3 - ozone gas alone $(200 \mathrm{mg} / \mathrm{h}) ; \mathrm{T} 4$ - photosensitisation and UV-C; T5 - photosensitisation and ozone gas; T6 - UV-C and ozone gas; T7 - photosensitisation + UV-C + Ozone gas and $\mathrm{C}$ - control. Error bars represents difference between different treatments on the same storages day.

\subsection{Changes in the activity of cell wall degrading enzyme PG of tomato}

PG plays an important task in depolymerisation of acidic pectin, and this phenomenon of this enzyme is responsible for the cell wall softening of the fruit while ripening (Gray et al., 1992). Changes in PG activity on cell wall component are depicted in Figure 6. PG enzyme activity on $0 \mathrm{~d}$ was $0.04 \mathrm{U} \mathrm{mg}^{-1}$ protein, while on 5 th $\mathrm{d}$ in PG activity of control 
expressed by the fruits was $0.10 \mathrm{U} \mathrm{mg}^{-1}$ protein and on other hand in tomatoes kept in $\mathrm{T} 1$ and $\mathrm{T} 5$ set expressed $0.04 \mathrm{U} \mathrm{mg}^{-1}$ protein activity of PG. More significant results were obtained on day 10th, where tomatoes treated with $\mathrm{T} 5$ showed $0.05 \mathrm{U} \mathrm{mg}^{-1}$ protein activities which were significantly lower than that of control, where control showed 0.29 $\mathrm{U} \mathrm{mg}^{-1}$ protein activity of PG. On 15th, 20th and 25th $\mathrm{d}$ of storage the PG activity showed by fruits kept in T5 was found to be $0.08 \mathrm{U} \mathrm{mg}{ }^{-1}$ protein, $0.10 \mathrm{U} \mathrm{mg}^{-1}$ protein and $0.14 \mathrm{U} \mathrm{mg}^{-1}$ protein respectively, while tomatoes kept in control set showed $0.20 \mathrm{U} \mathrm{mg}^{-1}$ protein, $0.11 \mathrm{U} \mathrm{mg}^{-1}$ protein respectively. These results indicate that the T5 and T1 able to slower down the process of production of PG. Physical elicitors slower down the mechanism of depolymerisation of pectin molecule was also reported by Toti et al. (2018).

Figure 6 Effect of photosensitisation, UV-C irradiation and ozone gas on PG activity

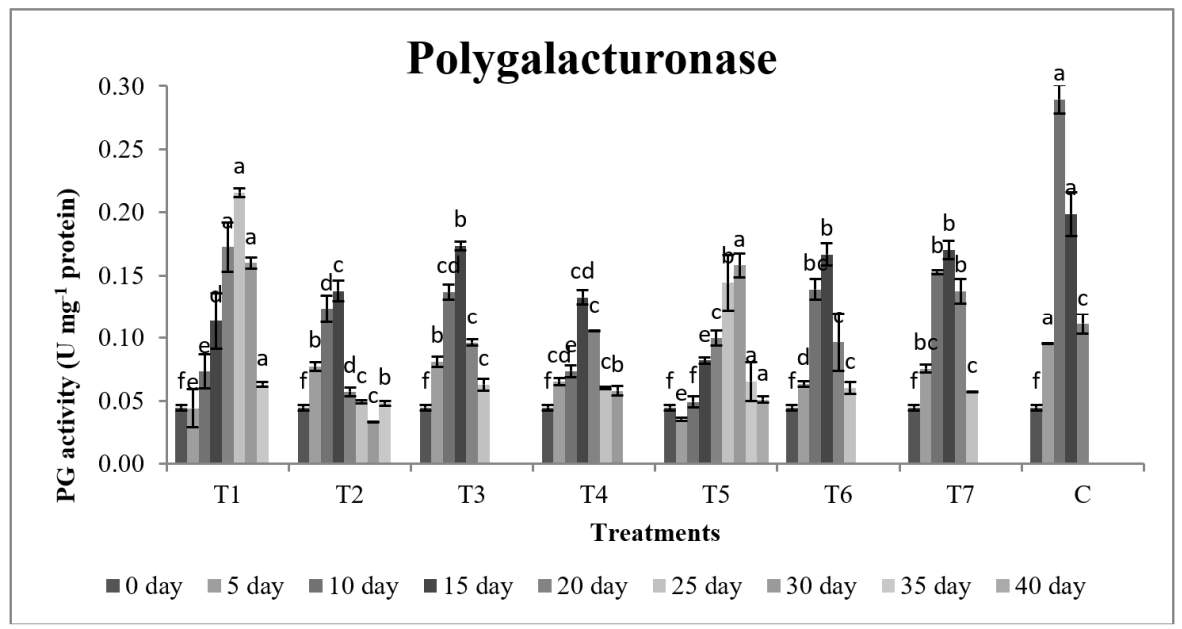

Notes: T1 - Photosensitisation alone; T2 - UV-C alone 210-280 nm; T3 - ozone gas alone $(200 \mathrm{mg} / \mathrm{h}) ; \mathrm{T} 4$ - photosensitisation and UV-C; T5 - photosensitisation and ozone gas; T6 - UV-C and ozone gas; T7 - photosensitisation + UV-C + ozone gas and $\mathrm{C}-$ control. Different letters over the Bars represents significant difference between different treatment on the same storages day at $P \leq 0.05$ according to DMRT.

\section{Conclusions}

The obtained results of the above conducted study conclude that the combination of physical elicitors like ozone gas and photosensitisation could successfully enhance the shelf life along with the maintenance of the antioxidant system of the tomatoes. This treatment of photosensitisation is novel and it did not negatively affect the fruit physiology and its nutritional composition. This combination successfully enhanced the shelf life of tomatoes by $18 \mathrm{~d}$ more than that of the control. Along with the enhancement of shelf life, this treatment also preserved the nutritional qualities. Further, the detailed study can also be conducted to check the efficacy of the photosensitisation treatment with or without other physical elicitors like ozone and UV-C on shelf life and postharvest diseases of any horticultural produce. 


\section{References}

Ahmed, F.A., Sipes, B.S. and Alvarez, A.M. (2017) 'Postharvest diseases of tomato and natural products for disease management', African Journal of Agricultural Research, Vol. 12, No. 9, pp.684-691.

Aidoo, R., Danfoku, R.A. and Mensah, J.O. (2014) 'Determinants of postharvest losses in tomato production in the Offinso North district of Ghana', Journal of Development and Agricultural Economics, Vol. 6, No. 8, pp.338-344.

AOAC (1994) Association of Official Analytical Chemists, Official Methods of Analysis, 16th ed., Arlington, Virginia, USA.

Arab, L. and Steck, S. (2000) 'Lycopene and cardiovascular disease', American Journal of Clinical Nutrition, Vol. 71, No. 6, pp.1691S-1695S.

Bico, S.L.S., Raposo, M.F.J., Morai, R.M.S.C. and Morais, A.M.M. (2009) 'Combined effects of chemical dip and/or carrageenan coating and/or controlled atmosphere on quality of fresh cut banana', Food Control, Vol. 20, No. 5, pp.508-514.

Brand-Williams, W., Cuvelier, M.E. and Berset, C.L.W.T. (1995) 'Use of a free radical method to evaluate antioxidant activity', LWT-Food Science and Technology, Vol. 28, No. 1, pp.25-30.

Cao, J.K., Jiang, W.B. and Zhao, Y.M. (2007) Experiment Guidance of Postharvest Physiology and Biochemistry of Fruits and Vegetables, pp.84-87, China Light Industry Press, Beijing.

Gray, J., Picton, S., Shabbeer, J. and Schuch, W. and Grierson, D. (1992) 'Molecular biology of fruit ripening and its manipulation with antisense genes', Plant Molecular Biology, Vol. 19, No. 1, pp.69-87.

Gutiérrez, D.R., Chaves, A.R. and Rodríguez, S.D.C. (2018) 'UV-C and ozone treatment influences on the antioxidant capacity and antioxidant system of minimally processed rocket (Eruca sativa Mill.)', Postharvest Biology and Technology, Vol. 138, pp.107-113.

Kapur, A., Haskovic, A., Copra-Janicijevic, A., Klepo, L., Topcagic, A., Tahirovicn, I. and Sofic, E. (2012) 'Spectrophotometric analysis of total ascorbic acid content in various fruits and vegetables', Bulletin of the Chemists and Technologists of Bosnia and Herzegovina, Vol. 38, No. 4, pp.39-42.

Kimura, S. and Sinha, N. (2008) 'Tomato (Solanum lycopersicum): a model fruit-bearing crop', Cold Spring Harbor Protocols, Vol. 3, No. 11, p.105.

Kumar, N., Tokas, J., Kumar, P. and Singal, H.R. (2018) 'Effect of salicylic acid on post-harvest quality of tomato (Solanum lycopersicum L.) fruit', Indian Journal of Chemical Studies, Vol. 6, No. 1, pp.1744-1747.

Lemoine, M.L., Chaves, A.R. and Martínez, G.A. (2010) 'Influence of combined hot air and UV-C treatment on the antioxidant system of minimally processed broccoli (Brassica oleracea $\mathrm{L}$. var. Italica)', LWT - Food Science and Technology, Vol. 43, No. 9, pp.1313-1319.

Lowry, O.H., Rosebrough, N.J., Farr, A.L. and Randall, R.J. (1951) 'Protein measurement with the folin phenol reagent', The Journal Biological Chemistry, Vol. 193, No. 1, pp.265-275.

Luksiene, Z. and Paskeviciute, E. (2011) 'Novel approach to the microbial decontamination of strawberries: chlorophyllin-based photosensitization', Journal of Applied Microbiology, Vol. 110, No. 5, pp.1274-1283.

Martínez-Castro, E., Jarquin-Gálvez, R., Alpuche-Solís, Á.G., Vallejo-Pérez, M.R., Colli-Mull, J.G. and Lara-Ávila, J.P. (2018) 'Bacterial wilt and canker of tomato: fundamentals of a complex biological system', Euphytica, Vol. 214, No. 4, p.72.

McDonald, S., Prenzler, P.D., Antolovich, M. and Robards, K. (2001) 'Phenolic content and antioxidant activity of olive extracts', Food Chemistry, Vol. 73, No. 1, pp.73-84.

Ong, M.K., Ali, A., Alderson, P.G. and Forney, C.F. (2014) 'Effect of different concentrations of ozone on physiological changes associated to gas exchange, fruit ripening, fruit surface quality and defence-related enzymes levels in papaya fruit during ambient storage', Scientia Horticulture, Vol. 179, pp.163-169. 
Paliyath, G., Murr, D.P., Handa, A.K. and Lurie, S. (2008) Postharvest Biology and Technology of Fruits, Vegetables and Flowers, Wiley-Blackwell, A John Wiley and Sons, Ltd., Publication, Singapore.

Pandiselvam, R., Sunoj, S., Manikantan, M.R., Kothakota, A. and Hebbar, K.B. (2017) 'Application and kinetics of ozone in food preservation', Ozone: Science \& Engineering, Vol. 39, No. 2, pp.115-126.

Paskeviciute, E. and Luksiene, Z. (2009) 'Effective non-thermal photosensitization-based decontamination of strawberries from microorganisms', Scientific Works of the Lithuanian Institute of Horticulture and Lithuanian University of Agriculture, Vol. 28, No. 4, pp.89-97.

Rodoni, L., Casadei, N., Concellón, A., Chaves Alicia, A.R. and Vicente, A.R. (2010) 'Effect of short-term ozone treatments on tomato (Solanum lycopersicum L.) fruit quality and cell wall degradation', Journal of Agricultural and Food Chemistry, Vol. 58, No. 1, pp.594-599.

Scott, G., Dickinson, M., Shama, G. and Rupar, M. (2018) 'A comparison of the molecular mechanisms underpinning high-intensity, pulsed polychromatic light and low-intensity UV-C hormesis in tomato fruit', Postharvest Biology and Technology, Vol. 137, pp.46-55.

Srivastava, M.K. and Dwivedi, U.N. (2000) 'Delayed ripening of banana fruit by salicylic acid', Plant Science, Vol. 158, Nos. 1-2, pp.87-96.

Toti, M., Carboni, C. and Botondi, R. (2018) 'Postharvest gaseous ozone treatment enhances quality parameters and delays softening in cantaloupe melon during storage at $6^{\circ} \mathrm{C}$ ', Journal of the Science of Food and Agriculture, Vol. 98, No. 2, pp.487-494.

Tucker, G.A., Seymour, G.B. and Taylor, J.E. (Eds.) (1993) Biochemistry of Fruit Ripening, pp.1-51, Chapman and Hall, London.

Tusiime, S.M. (2014) Evaluating Horticultural Practices for Sustainable Tomato Production in Kamuli, Uganda, Unpublished MSc dissertation, Iowa State University, Ames, Iowa, USA.

Wang, L.Z., Liu, L., Holmes, J., Kerry, J.F. and Kerry, J.P. (2007) 'Assessment of film-forming potential and properties of protein and polysaccharide-based biopolymer films', International Journal of Food Science \& Technology, Vol. 42, No. 9, pp.1128-1138.

Zambre, S.S., Venkatesh, K.V. and Shah, N.G. (2010) 'Tomato redness for assessing ozone treatment to extend the shelf life', Journal of Food Engineering, Vol. 96, No. 3, pp.463-468. 